Pak. J. Agri. Sci., Vol. 56(3), 747-752; 2019

ISSN (Print) 0552-9034, ISSN (Online) 2076-0906

DOI:10.21162/PAKJAS/19.6121

http://www.pakjas.com.pk

\title{
ENZYMATIC AND AFLATOXIN PRODUCTION POTENTIAL OF ASPERGILLUS FLAVUS
}

\author{
Saba Sana', Aftab Ahmad Anjum,,*, Tahir Yaqub, Muhammad Nasir² and Ali Ahmad ${ }^{3}$ \\ ${ }^{1}$ Department of Microbiology, University of Veterinary and Animal Sciences, Lahore Pakistan; ${ }^{2}$ Department of \\ Nutrition, University of Veterinary and Animal Sciences, Lahore Pakistan; ${ }^{3}$ Experimental Research Lab, \\ University of Health Sciences Lahore Pakistan. \\ "Corresponding author's e-mail: aftab.anjum@uvas.edu.pk
}

\begin{abstract}
Fungi especially Aspergillus species are potential candidates for production of mycotoxins and industrially important enzymes. Aspergillus flavus isolates (129) recovered from soil mixed with animal rations $(\mathrm{n}=145)$ had aflatoxins (17.82\%) and Enzymes (10.37\%) production potential. Quantity of detected Aflatoxins varied for different isolates i.e., 3.25 to $11622.24 \mathrm{ng}$, 21.34 to 194.47ng and 3.36 to 40.12ng per mL of Sabouraud's dextrose broth in case of $\mathrm{AFB}_{1}, \mathrm{AFB}_{2}$ and $\mathrm{AFG}_{1}$ as determined by High performance liquid chromatography. Optimization of non-toxigenic starch hydrolyzing A. flavus was carried out at different incubation temperatures $\left(22,30\right.$ and $\left.37^{\circ} \mathrm{C}\right), \mathrm{pH}(4.5,6$ and 7.5$)$ and substrates including maize, wheat bran and rice husk $(1,3$ and 5\% each) for incubation period of 7 days. In optimization experiments for starch hydrolysis, most of the A. flavus (86\%) produced highest enzyme (IU) at $37^{\circ} \mathrm{C}$ and $\mathrm{pH} 6$ quantified by Dinitrosalicylic method. Most of the isolates were able to produce enzymes using rice husk followed by maize. The highest quantity of enzyme was produced by A. flavus (179.88 $+1.71 \mathrm{IU})$ using one percent of maize at $\mathrm{pH} 6$ and $37^{\circ} \mathrm{C}$. It was concluded that indigenous non-toxigenic A. flavus can be used in food industry as biological source of starch hydrolyzing enzymes.
\end{abstract}

Keywords: Aspergillus flavus, starch hydrolysis, food industry, aflatoxins, substrates

\section{INTRODUCTION}

Aspergillus flavus is saprophytic fungi and common contaminants of agricultural products. It gets entry into crops in pre-harvest, post-harvesting and during harvesting period. Under favorable growth conditions, A. flavus produce toxic secondary metabolites called aflatoxins (Carry et al., 2018). Four major naturally occurring aflatoxins are $\mathrm{AFB}_{1}, \mathrm{AFB}_{2}$, $\mathrm{AFG}_{1}$, and $\mathrm{AFG} 2$. However, other important aflatoxins are $\mathrm{AFM}_{1}$ and $\mathrm{AFM}_{2}$ secreted in milk and meat of animals (Kumar, 2018). Aflatoxins are major safety concern in food industry because these suppress immune system and predispose to diseases, affect different organs (liver, kidneys and brain) and molecules (Protein and DNA) of living body (Wu et al., 2016).

Fungal species are also source of industrially important enzymes that hydrolyze carbohydrates, protein and lipids (Kumari et al., 2017). Aspergillus is a well-known genus for amylases production and has higher production potential among fungi (Souza and Magalhaes, 2010; Champreda et al., 2007). Aspergillus niger is the most important specie capable of producing amylases so far. Aspergillus flavus is also a good amylase producer (Shafique et al., 2010). Microbial (bacteria and fungi) sources of amylases are preferred over other sources (plants and animals) on industrial level because of their cost effectiveness, better quality of amylases and easy manipulation of microorganisms (Shafique et al., 2010; Bhanwar et al., 2014).

Amylases are amylolytic enzymes (Abe et al., 2015). Amylases ( $\alpha$-Amylase E.C.3.2.1.1, $\beta$-Amylase EC 3.2.1.2 and $\gamma$-Amylase EC 3.2.1.3) have wide spectrum of applications in various industries including paper, textile and pharmaceutical industry (Mehta and Satyanarayana, 2016). Amylases are also utilized in fermentation, brewing, detergents, baking (Silva et al., 2013) and distilling industry (Khalid-Bin-Ferdaus et al., 2018). Amylases application in food industry ranges from clearing fruit juices, starch syrups preparation, making cakes, bread making (dough preparation and anti-stalling agent), to sweetening agent (conversion of glucose to fructose (Singh $e t$ al., 2014; Mehta and Satyanarayana, 2016). Amylases are being used as feed supplement to improve the digestibility of starch based diets in birds (Onderci et al., 2006).

Amylases production potential of non-mycotoxin producing indigenous A. flavus soil isolates was determined and optimized under different physical and nutritional parameters. The non-toxigenic amylase producing A. flavus may be better candidate for amylases to be used on industrial level.

\section{MATERIALS AND METHODS}

Collection of soil samples: Soil samples having animal rations ( $\mathrm{n}=145)$ were randomly collected from livestock farms of 29 villages (one sample from each farm, selected 5 
farms/village) located in and around District Lahore, Pakistan in sterilized plastic zipper bags. Soil suspensions (10\%) for each sample were prepared in sterile normal saline, mixed using vortex and placed in vertical fashion at room temperature undisturbed till settling of soil debris (Henderson, 1961).

Isolation and identification of Aspergillus flavus: Soil suspensions (1 $\mathrm{mL}$ each) were poured on independent properly labeled growth free Sabouraud's dextrose agar (SDA) petri plates under sterile conditions. Spread plate technique was followed for inoculation of samples and incubated at $25 \pm 3^{\circ} \mathrm{C}$ for 3 to 5 days (Zafar et al., 2007). Plates were observed daily for fungal growth and photographed by digital camera (Samsung ES-80). The macroscopic features including fungal colony texture, shape, margins and deposition of colors in central and periphery were recorded. Slide cultures were prepared by placing a drop of melted agar on sterile glass slide, inoculation of spores from purified culture, covered with cover slip and incubated at $25 \pm 3^{\circ} \mathrm{C}$ by providing humidity. On appearance of visible growth cultured slides were observed under bright field compound microscope (Meiji Techno) at 100X and 400X magnifications. Microscopic characters observed and recorded were type of hyphae, presence of foot cell and types of asexual spores (Tsuneo, 2010).

Mycotoxins production: Isolates of A. flavus were screened for mycotoxins production as described by Gonzalez et al. (2005) with minor modifications. Sabouraud's dextrose broth culture flasks were wrapped with brown papers and incubated at $28^{\circ} \mathrm{C}$ temperature for 45 days. Extraction was carried out by mixing fungal culture $(12.5 \mathrm{~g})$ with chloroform $(45 \mathrm{~mL})$, methanol $(5 \mathrm{~mL}), \mathrm{NaCl}(2.5 \mathrm{~g})$ and distilled water $(5 \mathrm{~mL})$ in round bottom flasks and placed at $37^{\circ} \mathrm{C}$ for 30 minutes on shaking incubator. The mixtures were filtered through Whatman filter paper $(0.4 \mu)$ and extracts were dried by placing beakers at $50^{\circ} \mathrm{C}$. Mycotoxins produced were detected qualitatively using Thin Layer Chromatography (TLC). The isolates showed fluorescence were considered mycotoxins producers and excluded from remaining experiments. Mycotoxins producing isolates were further confirmed by High Performance Liquid Chromatography (HPLC) using the procedure of Sobolev (2007). The type and concentration of mycotoxins was determined with the help of standards chromatogram.

Amylases production: A. flavus non-toxigenic isolates were screened for amylase production on starch agar as described by Kim et al. (2011). Fungal spores were inoculated on agar and incubated at $25^{\circ} \mathrm{C}$ for 5 days. The amylase production was detected by pouring iodine solution onto the plate. The colonies showed zone of hydrolysis were considered as positive.

Optimization of amylase production by A. flavus was carried out using one factor one-time method. Standard inoculums of A. flavus spores $\left(10^{6}\right.$ per $\left.\mathrm{mL}\right)$ were cultured at three different temperatures, $\mathrm{pH}$ levels, and substrate with varying concentrations. Selected A. flavus isolates were cultured in basal medium having one percent of each selected substrates (rice husk, maize and wheat bran) at $\mathrm{pH} 6.0$ and incubated at 22, 28 and $37^{\circ} \mathrm{C}$ temperatures for one week. Optimum temperature was selected for each fungus isolate at which highest quantity of enzymes produced. In next experiment fungal isolates were cultured at 4.5, 6 and $7.5 \mathrm{pH}$ levels for each substrate using optimized temperature for 7 days. Suitable $\mathrm{pH}$ level for each fungus was recorded in relation to highest amylases production. Similarly, at optimum temperature and $\mathrm{pH}$ values, each of the fungal isolate was cultured using 1,3 and 5 percent concentration of each substrate for amylases production (Sethi et al., 2016). Qualitatively amylases production was detected by iodine test using method described by Yoo et al. (1987). Iodine solution $(20 \mu \mathrm{L})$ was added to one $\mathrm{mL}$ of filtrate having crude enzyme and mixed well. The reaction color was observed to detect the degree of starch hydrolysis.

Amylases were quantified by dinitro salicylic method using protocol described by Mitidieri et al. (2006). Soluble starch (1\%; pH 6) was mixed with filtrate in equal volume (1:1) and incubated at $37^{\circ} \mathrm{C}$ for 30 minutes. It was boiled for ten minutes by adding $3 \mathrm{~mL}$ of DNS (3-5, Dinitro salicylic acid) reagent. Absorbance was recorded at 570nm wavelength. Amylases were measured in term of Unit activity. One unit activity was defined as amount of enzyme which liberated one $\mu \mathrm{mol}$ of reducing sugars from substrate under assay conditions. For data analysis one-way ANOVA followed by Duncan's multiple range posthoc tests applied using Statistical Package for Social Sciences (SPSS version 16).

\section{RESULTS}

Fungal isolates purified from soil samples were identified based on macroscopic and microscopic characters. Colonies of A. flavus were initially white filamentous which converted to granular, dusty and green on maturation (Fig. 1a). There was no color on reverse side of colony. Microscopic characters observed at $400 \mathrm{X}$ magnification were hyaline septate hyphae, presence of vesicle, foot cell and phialospores in chains (Fig. 1b). Total fungi isolated from soil samples were 1101 and out of which 129 were A. flavus. Among these 23 A. flavus isolates were detected as aflatoxin producers. The aflatoxins detected and quantified were $\mathrm{AFB}_{1}, \mathrm{AFB}_{2}$ and $\mathrm{AFG}_{1}$ in range from 3.25 to $11622.24 \mathrm{ng}, 21.34$ to $194.47 \mathrm{ng}$ and 3.36 to $40.12 \mathrm{ng}$ per $\mathrm{mL}$ of Sabouraud's dextrose broth respectively. From total toxin producing isolates 18.4 percent were $\mathrm{AFB}_{1}, 4.6$ percent were $\mathrm{AFB}_{2}$ and 9.2 percent were $\mathrm{AFG}_{1}$ producers. From remaining 106 non-toxigenic isolates, 11 isolates (10.37\%) were able to hydrolyze starch (Fig. 3).

Seven non-toxigenic isolates of $A$. flavus (AFL-01, AFL-02, AFL-03, AFL-04, AFL-05, AFL-06 and AFL-07) showed complete hydrolysis were selected for optimization 
experiments. Amylase production was optimized with different substrates (maize, wheat bran and rice husk) at varying concentrations (1, 3 and 5\%) at different incubation temperatures $\left(22,30\right.$ and $\left.37^{\circ} \mathrm{C}\right)$ and $\mathrm{pH}$ levels (4.5, 6 and 7.5). Degree of starch hydrolysis was analyzed with refrence to dipicted colors. AFL-05 showed partial hydrolysis at $\mathrm{pH} 6$ using maize $(1 \%)$ at $37^{\circ} \mathrm{C}$ (Fig. 2).

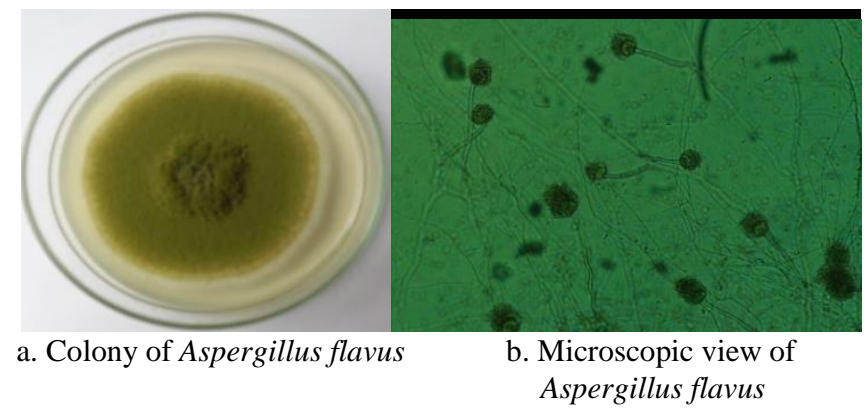

Figure 1. Macroscopic and microscopic characters of Aspergillus flavus isolate.
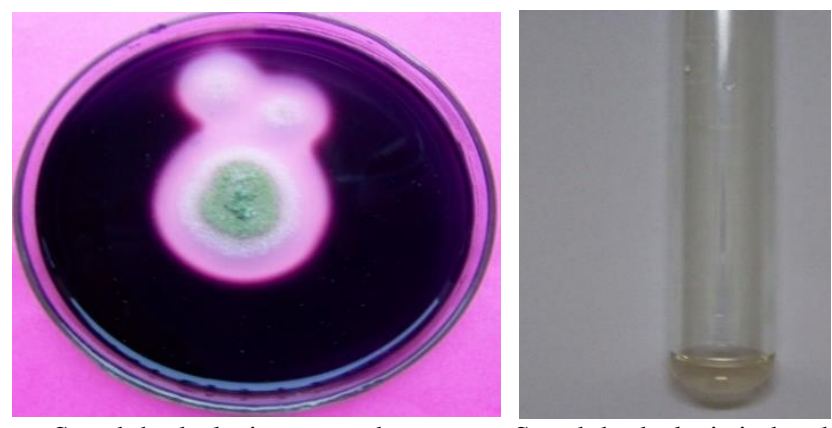

Starch hydrolysis on starch agar Starch hydrolysis in broth

Figure 2. Qualitative detection of amylases produced by Aspergillus flavus isolates.

All other six isolates (AFL-01, AFL-02, AFL-03, AFL-04, AFL-06 and AFL-07) showed complete hydrolysis represented by colorless solution. Among seven isolates of $A$. flavus, six isolates (AFL-01, AFL-02, AFL-03, AFL-04, AFL-05 and AFL-06) showed the highest enzyme production at $37^{\circ} \mathrm{C}$ and $\mathrm{pH} 6$ for amylase (Table 1). Rice husk proved best substrate for three isolates (AFL-03, AFL-04 and AFL-05) with concentration of one percent for AFL-04, AFL-05 and five percent for AFL-03 with amylase activities 128.60 \pm 8.90 , $99.17 \pm 2.49$ and $104.72 \pm .71 \mathrm{IU}$ respectively at $37^{\circ} \mathrm{C}$ and $\mathrm{pH} 6$. For AFL-06 maize (1\%) was optimum for highest enzyme yield (179.88 $\pm 1.71 \mathrm{IU})$. AFL-01 the highest amylase activity was $154.50 \pm 3.66$ at three percent wheat bran. The AFL-02 and AFL-07 showed highest enzyme yield at five percent concentrations of wheat bran which were $114.72 \pm .99$ and $119.01 \pm 1.42 \mathrm{IU}$, respectively (Table 2 and 3 ). The highest producer of amylase was AFL-06 (179.88 $\pm 1.71 \mathrm{IU})$. The optimum temperature for AFL- 07 was $22^{\circ} \mathrm{C}$, pH 7.5 and best substrate wheat bran with $5 \%$ concentration.

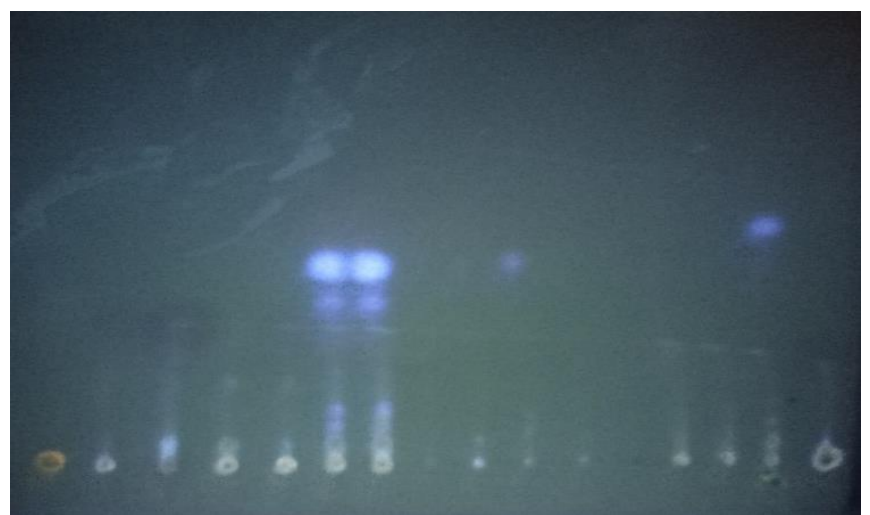

Thin layer chromatographic plate under Ultra-violet light (365nm)

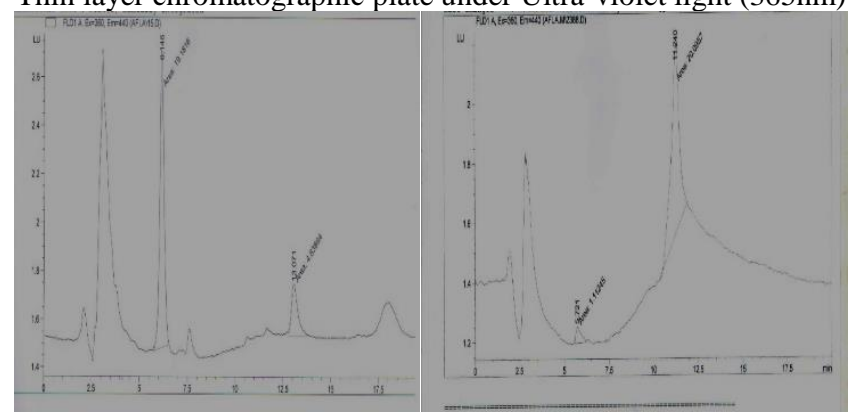

Representative picture of High Performance Liquid Chromatography of aflatoxins

Figure 3. Qualitative and quantitative detection of aflatoxins produced by Aspergillus flavus isolates.

Table 1. Growth optimization of Aspergillus flavus for amylases production at different temperatures using one percent substrate and $\mathrm{pH} 6$.

\begin{tabular}{llrrr}
\hline Substrate & Isolate \# & \multicolumn{1}{c}{$\mathbf{2 2}^{\circ} \mathbf{C}$} & \multicolumn{1}{c}{$\mathbf{2 8}^{\circ} \mathbf{C}$} & \multicolumn{1}{c}{$\mathbf{3 7}^{\circ} \mathbf{C}$} \\
\hline Maize & AFL-01 & $23.79 \pm 2.48 \mathrm{~b}$ & $9.92 \pm 0.17 \mathrm{a}$ & $61.42 \pm 0.46 \mathrm{c}$ \\
& AFL-02 & $3.39 \pm 0.27 \mathrm{a}$ & $9.33 \pm 0.40 \mathrm{~b}$ & $13.84 \pm 1.50 \mathrm{c}$ \\
& AFL-03 & $4.41 \pm 0.41 \mathrm{a}$ & $9.40 \pm 0.24 \mathrm{~b}$ & $18.10 \pm 0.17 \mathrm{c}$ \\
& AFL-04 & $6.28 \pm 0.58 \mathrm{a}$ & $10.75 \pm 0.18 \mathrm{~b}$ & $89.88 \pm 0.89 \mathrm{c}$ \\
& AFL-05 & $0.83 \pm 0.02 \mathrm{~b}$ & $11.22 \pm 0.17 \mathrm{c}$ & $0.08 \pm 0.00 \mathrm{a}$ \\
Wheat & AFL-06 & $3.02 \pm 0.25 \mathrm{a}$ & $11.47 \pm 0.34 \mathrm{~b}$ & $179.88 \pm 1.71 \mathrm{c}$ \\
bran & AFL-07 & $14.60 \pm 1.62 \mathrm{c}$ & $8.42 \pm 0.00 \mathrm{~b}$ & $2.48 \pm 0.09 \mathrm{a}$ \\
& AFL-01 & $5.68 \pm 0.16 \mathrm{a}$ & $5.84 \pm 0.16 \mathrm{a}$ & $29.73 \pm 0.17 \mathrm{~b}$ \\
& AFL-02 & $4.27 \pm 0.09 \mathrm{~b}$ & $4.70 \pm 0.16 \mathrm{c}$ & $1.78 \pm 0.16 \mathrm{a}$ \\
& AFL-03 & $6.98 \pm 0.16 \mathrm{c}$ & $3.78 \pm 0.09 \mathrm{a}$ & $5.65 \pm 0.17 \mathrm{~b}$ \\
& AFL-04 & $2.99 \pm 0.08 \mathrm{a}$ & $4.14 \pm 0.08 \mathrm{~b}$ & $11.11 \pm 0.30 \mathrm{c}$ \\
\multirow{5}{*}{ Ricehusk } & AFL-05 & $2.73 \pm 0.04 \mathrm{a}$ & $4.27 \pm 0.09 \mathrm{~b}$ & $7.02 \pm 0.14 \mathrm{c}$ \\
& AFL-06 & $6.16 \pm 0.16 \mathrm{~b}$ & $3.41 \pm 0.16 \mathrm{a}$ & $18.16 \pm 0.24 \mathrm{c}$ \\
& AFL-07 & $8.86 \pm 0.08 \mathrm{c}$ & $4.28 \pm 0.08 \mathrm{~b}$ & $0.13 \pm 0.01 \mathrm{a}$ \\
& AFL-01 & $24.89 \pm 0.93 \mathrm{~b}$ & $6.08 \pm 0.08 \mathrm{a}$ & $152.52 \pm 1.17 \mathrm{c}$ \\
& AFL-02 & $6.55 \pm 0.08 \mathrm{a}$ & $4.48 \pm 0.08 \mathrm{a}$ & $15.63 \pm 3.10 \mathrm{~b}$ \\
& AFL-03 & $7.25 \pm 0.09 \mathrm{~b}$ & $3.89 \pm 0.16 \mathrm{a}$ & $57.61 \pm 1.78 \mathrm{c}$ \\
& AFL-04 & $10.12 \pm 0.10 \mathrm{a}$ & $5.23 \pm 0.17 \mathrm{a}$ & $128.60 \pm 8.90 \mathrm{~b}$ \\
& AFL-05 & $6.20 \pm 0.22 \mathrm{a}$ & $4.26 \pm 0.09 \mathrm{a}$ & $99.17 \pm 2.49 \mathrm{~b}$ \\
& AFL-06 & $2.75 \pm 0.16 \mathrm{a}$ & $8.40 \pm 0.21 \mathrm{~b}$ & $156.68 \pm 1.24 \mathrm{c}$ \\
& AFL-07 & $7.72 \pm 0.08 \mathrm{c}$ & $3.52 \pm 0.09 \mathrm{~b}$ & $1.40 \pm 0.15 \mathrm{a}$ \\
\hline
\end{tabular}

Means carrying same superscript vary non-significantly, whereas means with different superscript differ significantly in rows. 
Table 2. Growth optimization of Aspergillus flavus for amylases production at different $\mathrm{pH}$ using $1 \%$ substrate and temperature $37^{\circ} \mathrm{C}$.

\begin{tabular}{llrrr}
\hline Substrate & Isolate \# & $\mathbf{4 . 5}$ & $\mathbf{6}$ & $\mathbf{7 . 5}$ \\
\hline Maize & AFL-01 & $3.65 \pm 0.08 \mathrm{a}$ & $61.42 \pm 0.46 \mathrm{c}$ & $4.61 \pm 0.08 \mathrm{~b}$ \\
& AFL-02 & $4.13 \pm 0.08 \mathrm{a}$ & $13.85 \pm 1.49 \mathrm{~b}$ & $5.75 \pm 0.08 \mathrm{a}$ \\
& AFL-03 & $3.98 \pm 0.08 \mathrm{a}$ & $18.10 \pm 0.17 \mathrm{c}$ & $5.09 \pm 0.08 \mathrm{~b}$ \\
& AFL-04 & $3.50 \pm 0.08 \mathrm{a}$ & $89.88 \pm 0.89 \mathrm{c}$ & $6.26 \pm 0.08 \mathrm{~b}$ \\
& AFL-05 & $3.81 \pm 0.08 \mathrm{~b}$ & $0.0842 \pm 0.00 \mathrm{a}$ & $4.05 \pm 0.00 \mathrm{c}$ \\
Wheat & AFL-06 & $3.63 \pm 0.19 \mathrm{a}$ & $179.88 \pm 1.71 \mathrm{~b}$ & $4.59 \pm 0.09 \mathrm{a}$ \\
bran & AFL-07 & $3.99 \pm 0.08 \mathrm{~b}$ & $2.48 \pm 0.09 \mathrm{a}$ & $4.64 \pm 0.08 \mathrm{c}$ \\
& AFL-01 & $7.11 \pm 0.31 \mathrm{a}$ & $29.73 \pm 0.17 \mathrm{c}$ & $7.96 \pm 0.16 \mathrm{~b}$ \\
& AFL-02 & $3.84 \pm 0.09 \mathrm{~b}$ & $1.78 \pm 0.16 \mathrm{a}$ & $4.92 \pm 0.09 \mathrm{c}$ \\
& AFL-03 & $3.73 \pm 0.16 \mathrm{a}$ & $5.65 \pm 0.17 \mathrm{~b}$ & $9.71 \pm 0.15 \mathrm{c}$ \\
& AFL-04 & $3.59 \pm 0.13 \mathrm{a}$ & $11.11 \pm 0.30 \mathrm{~b}$ & $3.77 \pm 0.17 \mathrm{a}$ \\
& AFL-05 & $3.75 \pm 0.13 \mathrm{a}$ & $7.01 \pm 0.14 \mathrm{~b}$ & $8.77 \pm 0.15 \mathrm{c}$ \\
& AFL-06 & $3.39 \pm 0.02 \mathrm{a}$ & $18.16 \pm 0.24 \mathrm{c}$ & $4.58 \pm 0.17 \mathrm{~b}$ \\
& AFL-07 & $3.89 \pm 0.16 \mathrm{~b}$ & $0.12 \pm 0.01 \mathrm{a}$ & $4.46 \pm 0.08 \mathrm{c}$ \\
& AFL-01 & $3.93 \pm 0.17 \mathrm{a}$ & $80.22 \pm 0.61 \mathrm{c}$ & $6.05 \pm 0.17 \mathrm{~b}$ \\
& AFL-02 & $9.86 \pm 0.01 \mathrm{~b}$ & $15.63 \pm 3.10 \mathrm{c}$ & $5.24 \pm 0.23 \mathrm{a}$ \\
& AFL-03 & $3.66 \pm 0.15 \mathrm{a}$ & $57.61 \pm 1.78 \mathrm{~b}$ & $4.75 \pm 0.17 \mathrm{a}$ \\
& AFL-04 & $4.04 \pm 0.01 \mathrm{a}$ & $128.60 \pm 8.90 \mathrm{~b}$ & $5.47 \pm 0.09 \mathrm{a}$ \\
& AFL-05 & $3.59 \pm 0.12 \mathrm{a}$ & $99.17 \pm 2.49 \mathrm{~b}$ & $4.42 \pm 0.17 \mathrm{a}$ \\
& AFL-06 & $3.36 \pm 0.10 \mathrm{a}$ & $156.68 \pm 1.24 \mathrm{~b}$ & $4.38 \pm 0.00 \mathrm{a}$ \\
& AFL-07 & $3.96 \pm 0.12 \mathrm{~b}$ & $1.40 \pm 0.15 \mathrm{a}$ & $5.82 \pm 0.13 \mathrm{c}$ \\
\hline
\end{tabular}

Means carrying same superscript vary non-significantly, whereas means with different superscript differ significantly in rows.

Table 3. Growth optimization of Aspergillus flavus for amylases production at different substrate concentrations at $\mathrm{pH} 6$ and temperature $37^{\circ} \mathrm{C}$

\begin{tabular}{lcrrr}
\hline Substrate & Isolate \# & \multicolumn{1}{c}{$\mathbf{1 \%}$} & $\mathbf{3 \%}$ & $\mathbf{5 \%}$ \\
\hline Maize & AFL-01 & $61.42 \pm 0.46 \mathrm{a}$ & $127.17 \pm 4.68 \mathrm{c}$ & $85.28 \pm 2.92 \mathrm{~b}$ \\
& AFL-02 & $13.85 \pm 1.49 \mathrm{a}$ & $75.76 \pm 3.74 \mathrm{~b}$ & $76.41 \pm 0.37 \mathrm{~b}$ \\
& AFL-03 & $18.10 \pm 0.17 \mathrm{a}$ & $79.00 \pm 6.75 \mathrm{~b}$ & $103.42 \pm 0.71 \mathrm{c}$ \\
& AFL-04 & $89.88 \pm 0.89 \mathrm{~b}$ & $92.43 \pm 7.00 \mathrm{~b}$ & $69.61 \pm 3.14 \mathrm{a}$ \\
& AFL-05 & $22.13 \pm 0.89 \mathrm{a}$ & $68.35 \pm 2.72 \mathrm{c}$ & $52.31 \pm 0.33 \mathrm{~b}$ \\
& AFL-06 & $179.88 \pm 1.71 \mathrm{c}$ & $47.49 \pm 0.78 \mathrm{a}$ & $98.70 \pm 3.95 \mathrm{~b}$ \\
Wheat & AFL-07 & $2.48 \pm 0.09 \mathrm{a}$ & $36.79 \pm 1.87 \mathrm{c}$ & $31.32 \pm 0.70 \mathrm{~b}$ \\
bran & AFL-01 & $29.73 \pm 0.17 \mathrm{a}$ & $154.50 \pm 3.66 \mathrm{c}$ & $99.14 \pm 1.63 \mathrm{~b}$ \\
& AFL-02 & $1.78 \pm 0.16 \mathrm{a}$ & $62.77 \pm 0.99 \mathrm{~b}$ & $114.72 \pm 0.99 \mathrm{c}$ \\
& AFL-03 & $5.65 \pm 0.17 \mathrm{a}$ & $28.68 \pm 2.47 \mathrm{~b}$ & $86.36 \pm 1.12 \mathrm{c}$ \\
& AFL-04 & $11.11 \pm 0.30 \mathrm{a}$ & $60.82 \pm 0.99 \mathrm{~b}$ & $123.51 \pm 1.31 \mathrm{c}$ \\
\multirow{6}{*}{ Rice husk } & AFL-05 & $7.01 \pm 0.14 \mathrm{a}$ & $73.72 \pm 0.97 \mathrm{~b}$ & $95.02 \pm 0.99 \mathrm{c}$ \\
& AFL-01 & $152.52 \pm 1.17 \mathrm{~b}$ & $102.00 \pm 4.16 \mathrm{a}$ & $98.40 \pm 1.72 \mathrm{a}$ \\
& AFL-06 & $18.16 \pm 0.24 \mathrm{a}$ & $34.02 \pm 0.93 \mathrm{~b}$ & $96.97 \pm 0.74 \mathrm{c}$ \\
& AFL-02 & $15.63 \pm 3.10 \mathrm{a}$ & $40.91 \pm 1.29 \mathrm{~b}$ & $96.36 \pm 3.74 \mathrm{c}$ \\
& AFL-03 & $57.61 \pm 1.78 \mathrm{~b}$ & $42.53 \pm 0.32 \mathrm{a}$ & $104.72 \pm 0.71 \mathrm{c}$ \\
& AFL-04 & $128.60 \pm 8.90 \mathrm{c}$ & $79.00 \pm 0.99 \mathrm{a}$ & $91.86 \pm 1.99 \mathrm{~b}$ \\
& AFL-05 & $99.17 \pm 2.49 \mathrm{c}$ & $80.30 \pm 1.35 \mathrm{~b}$ & $30.69 \pm 1.56 \mathrm{a}$ \\
& AFL-06 & $156.68 \pm 1.24 \mathrm{c}$ & $32.77 \pm 0.32 \mathrm{a}$ & $93.29 \pm 2.08 \mathrm{~b}$ \\
& AFL-07 & $1.40 \pm 0.16 \mathrm{a}$ & $48.27 \pm 1.35 \mathrm{c}$ & $17.20 \pm 0.85 \mathrm{~b}$ \\
\hline
\end{tabular}

Means carrying same superscript vary non-significantly, whereas means with different superscript differ significantly in rows.

\section{DISCUSSION}

Aspergillus flavus is a ubiquitous fungal species and found in soil and other substrates as contaminant. Soil is the main reservoir of aflatoxins producing A. flavus and a source of contamination to various food and feed materials. These contaminants grow and produce aflatoxins under favorable growth conditions and transmit these toxins to human and animal via food chain (Zhang et al., 2017). A. flavus was isolated from various types of samples and its aflatoxin production potential was detected. Zhang et al. (2017) isolated $94.2 \%$ A. flavus from field soil. This specie produced $\mathrm{AFB}_{1}$ ranged from 16501 to $82083 \mathrm{ng} / \mathrm{mL}$ is higher than present study. Fakruddin et al. (2015) recovered A. flavus from feed samples and 90 percent of these isolates were $\mathrm{AFB}_{1}$ producer in range from $7-22 \mathrm{ug} / \mathrm{g}$ of solid medium. ElHamaky et al. (2016) detected toxin producing aspergilli from feed samples and from 44 isolates of A. flavus, 33 contaminants were found as toxin producers. Raju et al. (2016) isolated toxigenic species of A. flavus along with other fungi from animal feed. Results of aflatoxin production of $A$. flavus isolates in present study are in contrast with Carranza et al. (2014). Carranza isolated 87.5 percent $A$. flavus out of which eight percent were toxigenic. The quantity of $\mathrm{AFB}_{1}$ was in range of $18 \cdot 0-84 \cdot 3 \mathrm{ng} / \mathrm{mL}$. However, $\mathrm{AFB}_{1}$ quantity is close to results of present study $(73.73 \mathrm{ng} / \mathrm{mL})$. The results of toxigenic A. flavus (27.5\%) are differed from RazzaghiAbyaneh (2006). Razzaghi-Abyaneh reported 87.9 percent of toxigenic A. flavus. The differences in results of toxigenic A.flavus prevalence in present study may be attributed to the presence of animal rations in soil samples from where the fungi were isolated.

Amylase is a valuable enzyme in starch-based industries having 30\% share in worldwide enzyme production. It can be obtained from plants and animals, but microorganisms are better choice for amylase production. Among microbes, Bacillus and Aspergillus are potential candidates for amylase production on industrial level (Wang et al., 2016). Filamentous fungi are famous for extracellular enzyme production. Aspergillus species; A. oryza and A. niger are well known for industrial amylases (Mathew et al., 2016). In a study conducted by Pathak and Narula (2013) starch hydrolyzing genera were Aspergillus, Fusarium and Rhizopus. A. flavus and A. niger were major species. Sohail et al. (2005) found 16.15 percent amylase producing fungi and A. flavus was 13.64 percent. Several physical and chemical factors such as temperature, $\mathrm{pH}$, carbon and nitrogen influence the amylase biosynthesis (Sethi et al., 2016).

Fungal growth is affected by nutritional and environmental conditions. The growth conditions for beneficial and industrially important fungal isolates can be optimized for enhanced production of desired products (Shafique et al., 2010). In present study, amylolytic A. flavus isolates were optimized under different physicho-chemical conditions. The production of amylases was quantified by detecting reducing sugar using DNS (Dinitro Salicylic Acid) method. The 
amount of reducing sugar is directly proportional to amylase activity (IU/mL). Several studies have been conducted in order to optimize the growth conditions for amylases production. The findings of optimization study of Bakri et al. (2009) and Shafique et al. (2009) differed from present study. The starch hydrolyzing isolates by Bakri et al. (2009) belonged to genus Aspergillus and showed the best result at alkaline pH. Kim et al. (2005) found optimal $\mathrm{pH}$ for Sphaeropsis pyriputrescens between 3 to 6 and the highest amylolytic activity in $\mathrm{pH} 3-4$. According to Pathak and Narula (2013), the optimum $\mathrm{pH}$ for A. flavus (10.3 IU/Ml), A. niger (18 IU/mL), Fusarium (6.66 IU/mL) and Rhizopus (15 $\mathrm{IU} / \mathrm{mL}$ ) was 9 in contrast to present study where only one isolate AFL-07 showed the best activity at alkaline $\mathrm{pH} 7.5$ and rests at $\mathrm{pH} 6$.

Ragunathan and Swaminathan (2005) carried out optimization study using solid state fermentation on amylase producing $A$. oryzae isolated from litter soil. The maximum specific activity $\left(380 \mathrm{U} / \mathrm{mg}\right.$ ) was found at temperature $35^{\circ} \mathrm{C}$ and $\mathrm{pH}$ 5. A linear relation was found between specific activity and addition of starch (1\%) to growth medium. The results are in corroboration to present study findings.

Effect of agriculture waste was evaluated on amylases production by Varalakshmi et al. (2009). A. niger produced higher amylase units when growing on wheat bran at $22^{\circ} \mathrm{C}$ and $7.5 \mathrm{pH}$. The results strengthened the findings of present study as similar results were obtained by AFL-07. Oladapo (2013) used maize sorghum, cassava peel and soluble starch as substrates to grow starch hydrolyzing A. flavus. Oladapo concluded that amylase activity increased with increase in substrate concentration up to two percent. Higher percentage negatively affected amylase production of A. flavus.

Optimum conditions for higher amylase production vary with the source from which that fungal specie has been isolated. Both physical and nutritional factors required to be optimized for better production of enzymes. It was concluded that indigenous non-toxigenic A. flavus isolates are better and safe producers of amylases. Agriculture waste products can be used for cost effective production of amylases.

Conclusion: Indigenous A. flavus isolates are potential candidates for aflatoxins and enzyme production under optimized conditions.

Acknowledgements: The research was supported by Department of Microbiology, University of veterinary and Animal Sciences Lahore Pakistan and funded by Higher Education Commission (Purification and standardization of mycotoxins extracted from indigenous toxigenic fungi under optimized experimental conditions (4148).

\section{REFERENCES}

Abe, C.A.L., C.B. Faria, F.F. de Castro, S.R. de Souza, F.C.D.
Santos, C.N. da Silva and I.P. Barbosa-Tessmann. 2015. Fungi isolated from maize (Zea mays L.) grains and production of associated enzyme activities. Int. J. Mol. Sci. 16:15328-15346.

Bakri, Y., M. Magali and P. Thonart. 2009. Isolation and identification of a new fungal strain for amylase biosynthesis. Pol. J. Microbiol. 58:269-273.

Bhanwar, S., A. Singh and A. Ganguli. 2014. Probiotic characterization of potential hydrolases producing Lactococcus lactis subsp. lactis isolated from pickled yam. Int. J. food. Sci. Nutr. 65:53-61.

Carranza, C.S., M.V. Bergesio, C.L. Barberis, S.M. Chiacchiera and C.E. Magnoli. 2014. Survey of Aspergillus section Flavi presence in agricultural soils and effect of glyphosate on nontoxigenic A. flavus growth on soil-based medium. J. Aapp. Microbial. 116:1229-1240.

Cary, J.W., M.K. Gilbert, M.D. Lebar, R. Majumdar and A.M. Calvo. 2018. Aspergillus flavus secondary metabolites: More than just aflatoxins. Food. Saf. 6:7-32.

Champreda, V., P. Kanokratana, R. Sriprang, S. Tanapongpipat and L. Eurwilaichitr. 2007. Purification, biochemical characterization, and gene cloning of a new extracellular thermotolerant and glucose tolerant maltooligosaccharide-forming $\alpha$-amylase from an endophytic ascomycete Fusicoccum sp. BCC4124. Biosci. Biotechnol. Biochem. 71:2010-2020.

El-Hamaky, A.M., A.A. Hassan, H.A. El Yazeed and M.K. Refai. 2016. Prevalence and detection of toxigenic $A$. flavus, A. niger and A. ochraceus by traditional and molecular biology methods in feeds. Int. J. Curr. Res. 8:25621-25633.

Fakruddin, M., A. Chowdhury, M.N. Hossain and M.M. Ahmed. 2015. Characterization of aflatoxin producing Aspergillus flavus from food and feed samples. Springer Plus 4:159-165.

Gonzalez, G., M.J. Hinojo, R. Mateo, A. Medina and M. Jiménez. 2005. Occurrence of mycotoxin producing fungi in bee pollen. Int. J. Food Microbial. 105:1-9.

Henderson, M.E. 1961. Isolation, identification and growth of some soil hyphomycetes and yeast-like fungi which utilize aromatic compounds related to lignin. Microbiol. 26:149-154.

Ferdaus, K.B.K.Md., Md. Forhad Hossain, S.A. Mansur, S.A. Sajib, Md. M. Miah, K. Md. F. Hoque, Md. A. Reza. 2018. Commercial production of alpha amylase enzyme for potential use in the textile industries in Bangladesh. Int. J. Biosci. 13:149-157.

Kim, H.R., J.H. Kim, D.H. Bai and B.H. Ahn. 2011. Identification and characterization of useful fungi with $\alpha$ amylase activity from the Korean traditional Nuruk. Mycobiol. 39:278-282.

Kim, Y.K., C.L. Xiao and J.T. Rogers. 2005. Influence of culture media and environmental factors on mycelial growth and pycnidial production of Sphaeropsis pyriputrescens. Mycologia 97:25-32. 
Kumar, V.V. 2018. Aflatoxins: Properties, toxicity and detoxification. Nutri Food. Sci. Int. J. 6:555-696.

Kumari, D., Z. Abideen, M. Sohail, S. Jahangeer, B. Gul, M.A. Khan and S.A. Khan. 2017. Plant cell-wall hydrolyzing enzymes from indigenously isolated fungi grown on conventional and novel natural substrates. Pak. J. Bot. 49:745-750.

Mathew, J.J., P.J. Vazhacharickal, N.K. Sajeshkumar and A. Ashokan. 2016. Amylase production by Aspergillus niger through submerged fermentation using starchy food byproducts as substrate. Int. J. Herb. Med. 4:34-40.

Mehta, D. and T. Satyanarayana. 2016. Bacterial and archaeal $\alpha$-Amylases: Diversity and amelioration of the desirable characteristics for industrial applications. Front. Microbiol. 7:1129-1150.

Mitidieri, S., A.H.S. Martinelli, A. Schrank and M.H. Vainstein. 2006. Enzymatic detergent formulation containing amylase from Aspergillus niger: A comparative study with commercial detergent formulations. Bioresou. Technol. 97:1217-1224.

Oladapo, O.M. 2013. Optimization of growth and amylase production by Aspergillus flavus grown on some agricultural raw materials in Nigeria. Pak. J. Nutr. 12:427-432.

Onderci, M., N. Sahin, K. Sahin, G. Cikim, A. Aydın, I. Ozercan and S. Aydın. 2006. Efficacy of supplementation of $\alpha$-amylase-producing bacterial culture on the performance, nutrient use, and gut morphology of broiler chickens fed a corn-based diet. Poult. Sci. 85:505-510.

Pathak, S. and N. Narula. 2013. Optimization of $\mathrm{pH}$ for the production of amylase by soil mycotic flora of Jabalpur region. Res. Rev. J. Microbiol. Biotechnol. 2:17-22.

Ragunathan, R. and K. Swaminathan. 2005. Growth and amylase production by Aspergillus oryzae during solid state fermentation using banana waste as substrate. J. Environ. Boil. 26:653-656.

Raju, S., C.J. Padamadan and N.H. Shenpagam. 2016. Mycotoxin production by fungi isolated from commercially prepared livestock feed in Kerala. Int. J. Appl. Res. 2:154-159.

Razzaghi-Abyaneh, M., M. Shams-Ghahfarokhi, A. Allameh, A. Kazeroon-Shiri, S. Ranjbar-Bahadori, $\mathrm{H}$. Mirzahoseini and M.B. Rezaee. 2006. A survey on distribution of Aspergillus section Flavi in corn field soils in Iran: population patterns based on aflatoxins, cyclopiazonic acid and sclerotia production. Mycopathol. 161:183-192.

Sethi, B.K., A. Jana, P.K. Nanda, P.K. DasMohapatra, S.L. Sahoo, and J.K. Patra. 2016. Production of $\alpha$-amylase by Aspergillus terreus NCFT 4269.10 using pearl millet and its structural characterization. Front. Plant Sci. 7: 639-652.
Shafique, S., R. Bajwa and S. Shafique. 2009. Screening of Aspergillus niger and A. flavus strains for extra cellular alpha-amylase activity. Pak. J. Bot. 41:897-905.

Shafique, S., R. Bajwa and S. Shafique. 2010. Condition stabilization for Aspergillus niger FCBP-198 and its hyperactive mutants to yield high titers of $\alpha$-amylase. Microbiol. 79:301-306.

Silva, T.M., A.R.L. Damasio, A. Maller, M. Michelin, F.M. Squina, J.A. Jorge and M.L.T.M. Polizeli. 2013. Purification, partial characterization, and covalent immobilization-stabilization of an extracellular $\alpha$ amylase from Aspergillus niveus. Folia. Microbiol. 58:495-502.

Singh, S., S. Singh, V. Bali, L. Sharma and J. Mangla. 2014. Production of fungal amylases using cheap, readily available agriresidues, for potential application in textile industry. BioMed. Res. Int. 4:1-9.

Sobolev, V.S. 2007. Simple, rapid, and inexpensive cleanup method for quantitation of aflatoxins in important agricultural products by HPLC. J. Agric. Food Chem. 55:2136-2141.

Sohail, M., A. Ahmad, S. Shahzad and S.A. Khan. 2005. A survey of amylolytic bacteria and fungi from native environmental samples. Pak. J. Bot. 37:155-161.

Souza, P.M.D. and P.D.O. Magalhaes. 2010. Application of microbial $\alpha$-amylase in industry- A review. Braz. J. Microbiol. 41:850-861.

Tsuneo, W. 2010. Pictorial atlas of soil and seed fungi: Morphologies of cultural fungi and key to species, $3^{\text {rd }} \mathrm{Ed}$. Taylor and Francis Group CRC press., Florida.

Varalakshmi, K.N., B.S. Kumudini, B.N. Nandini, J. Solomon, R. Suhas, B. Mahesh and A.P. Kavitha. 2009. Production and characterization of a-Amylase from Aspergillus niger JGI 24 isolated in Bangalore. Pol. J. Microbiol. 58:29-36.

Wang, S., J. Jeyaseelan, Y. Liu and W. Qin. 2016. Characterization and optimization of amylase production in Wang LB, a high amylase-producing strain of Bacillus. Appl. Biochem. Biotechnol. 180:136-151.

Wu, L., J. Li, Y.Li, T. Li, Q. He, Y. Tang and P. Liao. 2016. Aflatoxin B 1, zearalenone and deoxynivalenol in feed ingredients and complete feed from different province in China. J. Anim. Sci. Biotechnol. 7:63-73.

Yoo Y.J., J. Hong and R.T. Hatch. 1987. Comparison of aamylase activities from, different assay methods. Biotechnol. Bioeng. 30:147-151.

Zafar, S., F. Aqil and I. Ahmad. 2007. Metal tolerance and biosorption potential of filamentous fungi isolated from metal contaminated agricultural soil. Bioresour. Technol. 98:2557-2561.

Zhang, C., J. Selvaraj, Q. Yang and Y. Liu. 2017. A survey of aflatoxin-producing Aspergillus sp. from peanut field soils in four agroecological zones of China. Toxins 9:40-54. 